\title{
Identify Sustainable Livelihood in Small Island
}

\author{
Nurul Sri Rahatiningtyas \\ Department of Geography \\ Indonesia University \\ Depok, Indonesia \\ Corresponding email: nurul.sr@ui.ac.id \\ Elgodwistra Kartikoputro \\ Department of Geography \\ Indonesia University \\ Depok, Indonesia
}

\begin{abstract}
Small island communities are people who depended on natural resources. The high potential of natural resources in small island not always followed by high welfare of the communities. Kepulauan Seribu in north part of Jakarta is one of small island that still depended on natural resources for their livelihood. As a small island community, most of the population working as catching and cultivation fisherman. Seaweed farming is one of the most potential resources in Kepulauan Seribu. Recent years, Environmental degradation has affected seaweed farming in Kepulauan Seribu. This research will talk about how the vulnerability of fisherman livelihoods based on sustainable seaweed farming assets (natural, physical, social, human, and finance) in Kepulauan Seribu? And how the effects of seaweed farming on the sustainability of the livelihoods in Kepulauan Seribu communities? Identification sustainable livelihood in this research will focus on Sustainable Livelihood Framework.
\end{abstract}

Keywords - Sustainable Livelihood Framework, small Island, seaweed farmers, assets

\section{INTRODUCTION}

Coastal and small islands are known as natural resources potential area. These resources consist of the fishery (catch and aquaculture), mining, pharmaceuticals, alternative energy from waves and currents, as well as natural resources as supporting the activities of transport, defense and security, and tourism.

DKI Jakarta is one of the provinces that have coastlines and small islands, and the economic potential of marine and fisheries sector. Administratively, DKI Jakarta consists of 5 areas (City of West Jakarta, South Jakarta, East Jakarta, North Jakarta and Central Jakarta) and one district (Kepulauan Seribu District). In 2015, DKI Jakarta has a land area of $662.33 \mathrm{~km} 2$ and sea area $6977.5 \mathrm{~km} 2$, with population density $15.367 / \mathrm{km}^{2}$. It makes DKI Jakarta as the most densities province in Indonesia. Population Growth Rate of DKI Jakarta in 2015 is 1.02\% (DKI Jakarta Province Statistic Bureau, 2015). The population growth rate of Kepulauan Seribu District is the highest compared to other areas in Jakarta which amounted to
$2.02 \%$, while the lowest in Central Jakarta City Administration which amounted to $0.27 \%$ (DKI Jakarta Province Disaster Management Bureau, 2011).

In 2011, fisheries production in DKI Jakarta reached $180.197,9$ tons. The largest contribution was obtained from the City of North Jakarta reached 178.613,9 ton; the next is the Kepulauan Seribu District which reached 1.584 tons (Centre of Data, Statistic, and Information, 2013).

Most coastal communities depend on fisheries (Kusnadi, 2009). The high potential of resources in coastal areas and small islands are not followed by high welfare of the communities. According to Kusnadi (2009) as well as other communities, coastal communities has problems such as (1) poverty, social inequality, and economic pressures; (2) limited access to capital, technology and markets, thereby affecting the dynamics of the business; (3) the weakness of the institutional functions of the existing socio-economic; (4) the quality of human resources as a result of lack access to education, health, and public services; (5) degradation of environmental resources, both in coastal areas, sea, or on small islands; and (6) not strong maritime-oriented policy as the main pillar of national development.

This research aims are to analyze the vulnerability to identifying the sustainability of its assets in small islands. As for the question on the issue of this research are:

- How coastal community vulnerable based on sustainable livelihood assets in the Kepulauan Seribu?

- How does the cultivation of seaweed can make sustainability of the livelihoods of the Kepulauan Seribu?

\section{METHOD}

Sustainable livelihoods identification in this research is using sustainable livelihood framework. Sustainable livelihood 
itself is a term to describes the capability, ownership of resources (material and social resources), and activities required for a person/people to live their lives. Livelihood will be sustained if the people/communities could deal with and recover from stresses and shocks, manage and strengthen the capability, and ownership of resources (assets) for the welfare/society today (now) and community/future life, and does not degrade the quality of the existing natural resources (Saragih et al, 2007).

This research will talk about stock events such as natural disasters, technological disasters, conflict, change of seasons, and the economic crisis. While the assets identified by human capital, natural capital, social capital, physical capital, and financial capital. As for the things that are included in each of these assets are:

- Human capital - education, access to health facilities, and skills.

- Natural capital - land, commodities, and access to water.

- Social capital - family member who can be relied upon during the crisis, members of certain associations, and occupation.

- Physical capital - accessibility and quality of house.

- Financial capital - yields, ownership of goods, income, and savings.

\section{Sustainable livelihoods framework}

\begin{tabular}{|ll|}
\hline Key & \\
$\mathrm{H}=$ Human Capital & $\mathrm{S}=$ Social Capital \\
$\mathrm{N}=$ Natural Capital & $\mathrm{P}=$ Physical Capital \\
$\mathrm{F}=$ Financial Capital & \\
\hline
\end{tabular}

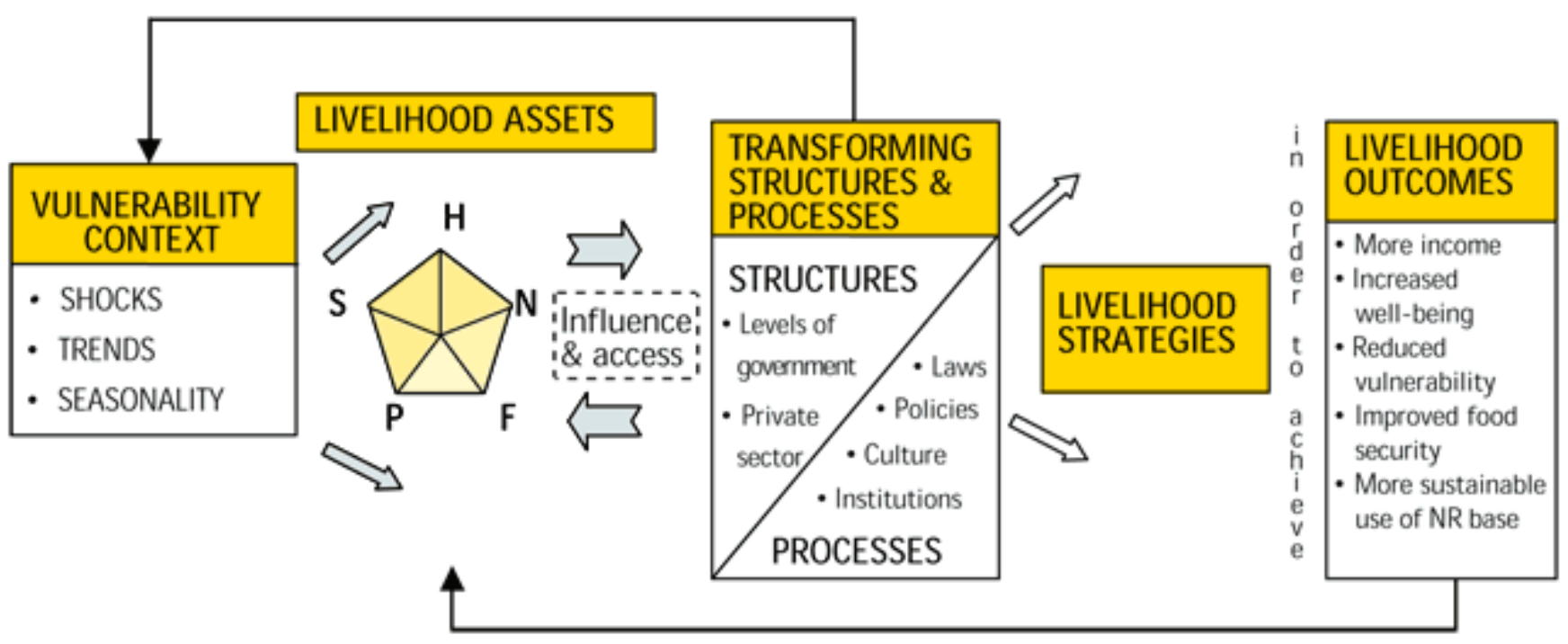

Fig. 1. Sustainable Livelihood Framework

Source: Modified from DFID 1999, Sustainable Livelihood Guidance Sheets (Saragih et al, 2007). 


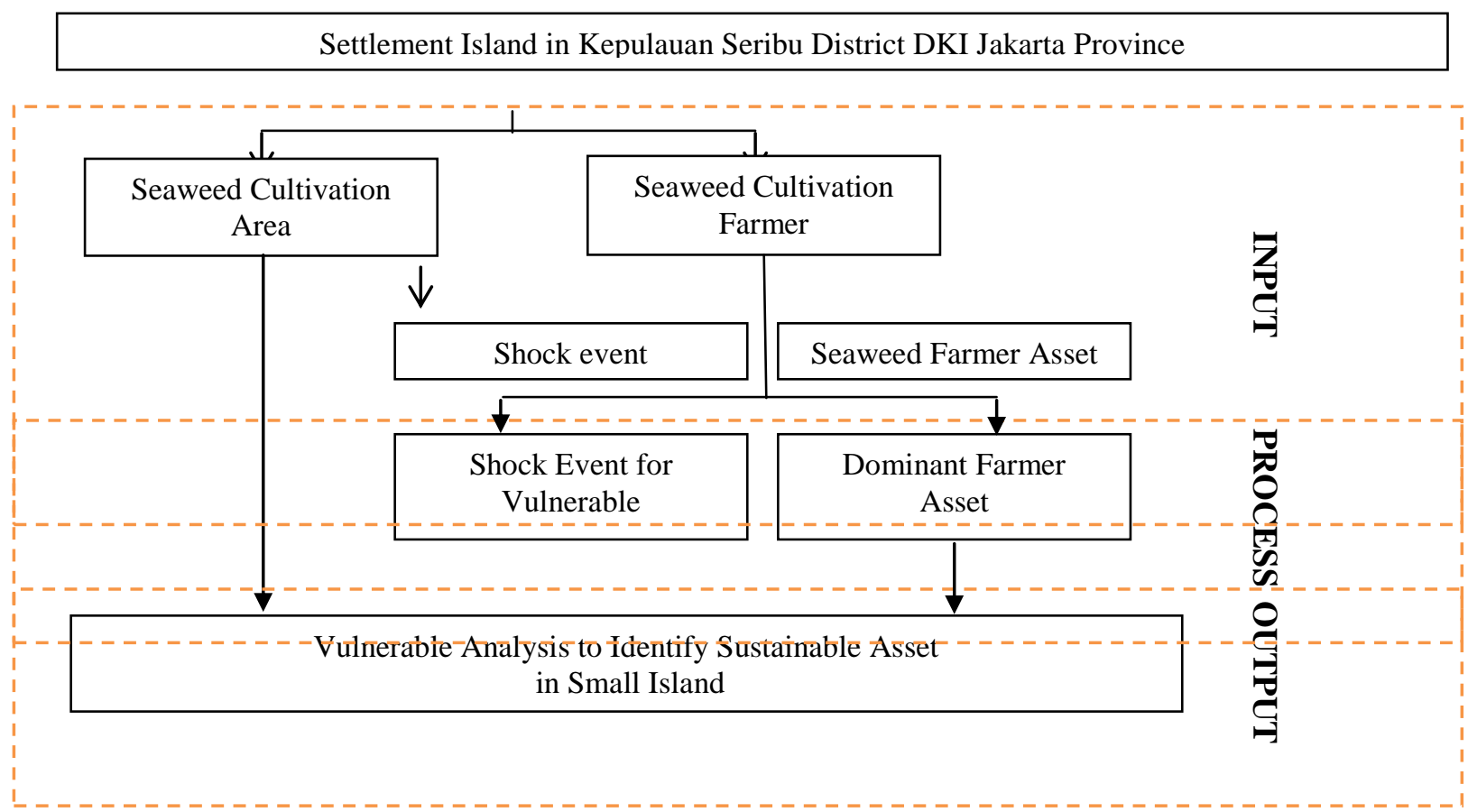

Fig. 2. Research Framework

The data used in this study include:

A. Secondary data from desk study, include:

- Kepulauan Seribu population data related to livelihood.

- Kepulauan Seriibu coastal resources data related to seaweed cultivation.

- The previous study related to seaweed cultivation, coastal communities, and sustainable livelihood framework.

B. Primary data

- The location of seaweed farming.

- Shock events (natural disasters, technological disasters, conflict, change of seasons, and the economic crisis).

- Farmer assets (human capital, natural capital, social capital, physical capital, and financial capital).

Secondary and primary data are used to analyzed and to see how vulnerable seaweed farmer in Kepulauan Seribu.

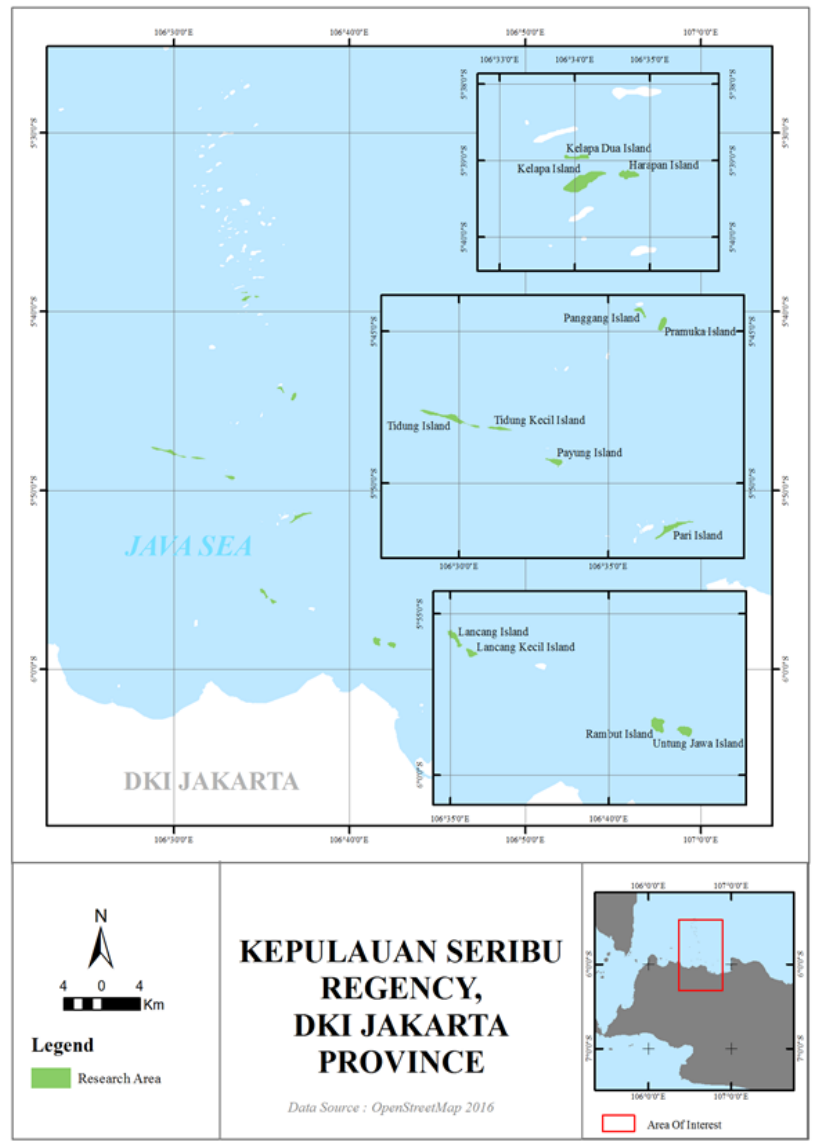

Fig. 3. Research Area 


\section{FINDING AND DISCUSSION}

\section{A. Seaweed Cultivation and Kepulauan Seribu District}

Seaweed is one of the coastal resources that can be grown naturally and are also cultivated. The high demand and lack of stock naturally, causing these commodities began to cultivate. Seaweed is a commodity that experienced a substantial increase. Aquaculture production by major commodity in Indonesia in 2009-2014 can be seen in the following table.

TABLE 1. AQUACULTURE PRODUCT IN INDONESIA 2009-2014

Satuan: Ton

Unit: Ton

\begin{tabular}{|c|c|c|c|c|c|c|c|c|}
\hline \multirow{2}{*}{$\begin{array}{l}\text { Jenis Ikan - } \\
\text { Species }\end{array}$} & \multicolumn{6}{|c|}{ Tahun - Year } & \multicolumn{2}{|c|}{$\begin{array}{l}\text { Kenaikan Rata-Rata (\%) } \\
\text { Increasing Average (\%) }\end{array}$} \\
\hline & 2009 & 2010 & 2011 & 2012 & 2013 & $\left.2014^{*}\right)$ & 2009-2013 & 2012-2013 \\
\hline Jumlah-Total & 4.708 .565 & 6.277 .923 & 7.928 .962 & 9.675 .553 & 13.300 .906 & 14.521 .349 & 29,78 & 37,47 \\
\hline \multicolumn{9}{|l|}{ Produksi-Production } \\
\hline 1. Rumput Laut - Seaweed & 2.963 .556 & 3.915 .017 & 5.170 .201 & 6.514 .854 & 9.298 .474 & 10.234 .357 & 33,23 & 42,73 \\
\hline 2.Udang - Shrimp & 338.060 & 380.972 & 400.385 & 415.703 & 645.955 & 592.219 & 19,25 & 55,39 \\
\hline 3. Kerapu - Groupers & 5.073 & 10.398 & 10.580 & 11.950 & 18.864 & 12.430 & 44,38 & 57,85 \\
\hline 4. Kakap-Giant seaperch & 6.400 & 5.738 & 5.236 & 6.198 & 6.735 & 4.439 & 1,99 & 8,66 \\
\hline 5. Bandeng - Milk fish & 328.288 & 421.757 & 467.449 & 518.939 & 627.333 & 621.393 & 17,80 & 20,89 \\
\hline 6. Ikan Mas - Common carp & 249.279 & 282.695 & 332.206 & 374.366 & 412.703 & 484.110 & 13,46 & 10,24 \\
\hline 7. Nila - Nile Tilapia & 323.389 & 464.191 & 567.078 & 695.063 & 914.778 & 912.613 & 29,97 & 31,61 \\
\hline 8. Lele-Catfish & 144.755 & 242.811 & 337.577 & 441.217 & 543.774 & 613.120 & 40,18 & 23,24 \\
\hline 9. Patin - Catfish & 109.685 & 147.888 & 229.267 & 347.000 & 410.883 & 403.133 & 39,90 & 18,41 \\
\hline 10. Gurame - Giant Gouramy & 46.254 & 56.889 & 64.252 & 84.681 & 94.605 & 108.180 & 19,86 & 11,72 \\
\hline 11. Lainnya-Others & 193.826 & 349.568 & 344.731 & 265.580 & 326.801 & 535.355 & 19,76 & 23,05 \\
\hline
\end{tabular}

The province which is the largest producer of seaweed production in 2013 are South Sulawesi (2,4 million tons), East Nusa Tenggara (1,8 million tons), Central Sulawesi Province (1,2 million tons), and Southeast Sulawesi Province (917 thousand tons) (Centre of Data, Statistics and Information, 2014). DKI Jakarta also produces seaweed as one of marine aquaculture production. The results of marine aquaculture production in Jakarta in 2011 were (Centre of Data, Statistic, and Information, 2013):

- Kakap for 253.583 tons.

- Bandeng for 176.347 tons.

- Bawal Bintang and Rajungan for 176.347 tons.

- Rumput Laut (Seaweed) amounted to 30,400 tons.

- Kerapu for 6,780 tons.

Number of Fisheries households (RTP) in Jakarta, especially in Kepulauan Seribu District in 2011 recorded decreased from 614 units in 2010 to 330 in 2011. The net area of marine aquaculture area in Jakarta in 2011 also decreased from the 60.39 hectares in 2011 to 53.40 hectares in 2012 (Centre of Data, Statistics and Information, 2013). Seaweed cultivation areas in Kepulauan Seribu focus in Panggang and Pramuka Island.

\section{B. Vulnerability Seaweed Farmers in Kepulauan Seribu District}

According to Khotimah (2015), seaweed cultivation in Panggang Island has started since 1986. The species of the seaweed are Eucheuma cottonii. Seaweed cultivation method was first taught by the Department of Marine to farmers is the technique of off-bottom method. This technique is considered quite complicated because farmers have to dive into the sea for planting and harvesting. Furthermore, in 1989 the farmers developed the new technique that is the floating rafts method. However, these techniques cannot supply the demand. Then in 1991, farmers in Panggang Island developed a new technique that is a long-line method. In 2000, there are Hugh reductions of seaweed production in Kepulauan Seribu District. Farmers have tried to replant the seaweed but always failed. The new seed becomes damaged and rotten. Since that time, there was no seaweed cultivation in Kepulauan Seribu District.

Starting in 2013, one of the farmers in Kepulauan Seribu District begin to try to grow seaweed. Seaweed seed start to grow well in mid-2014. According to the farmers on Panggang Island, successes and failures of seaweed cultivation are affected by changes in the harvesting season. Western monsoon season can cause bad weather in this area. While planting in eastern monsoon season the seed will grow well and the farmer could harvest the seaweed (Khotimah, 2015).

The important factor for seaweed cultivation is the location. The location for seaweed cultivation should consider several things, such as (a) the location must be free from material contaminated, (b) should be away from the current heavy traffic, and (c) a strategic location for marketing the seaweed (Khotimah, 2015 ).

One of the farmer on Panggang Island, are located the seaweed farm within approximately $50 \mathrm{~m}$ from the mainland. 
Location seaweed cultivation should not close to traffic lanes; the water flows slowly and there are ripples tiny waves; should not be exposed to high waves; and the depth of the water should be maintained so that the water remains at its lowest ebb (Khotimah, 2015).

Based on previous research (Khotimah, 2015) note that the location of seaweed cultivation in Panggang Island has a $\mathrm{pH}$ value of 7 (neutral), a temperature value between $29,5-31^{\circ} \mathrm{C}$, and salinity values around $33-35 \mathrm{ppm}$. This value is slightly different from the opinions Sahoo and Yarish (2005) which states that the optimum location of seaweed area has a value of $27-30{ }^{\circ} \mathrm{C}$ temperature and $30-33 \mathrm{ppm}$ salinity. This can affect the production of Eucheuma produced. The optimal temperature increases the absorption of nutrients so as to accelerate the growth of seaweed because it will give the smoothness and ease of metabolism (Khotimah, 2013). Higher temperatures cause many sunlight into the water so that the seeds Eucheuma be easier to dry. According to Choi et al (2010) in Khotimah (2013), seaweed will slow growth, if the salinity is too low (less than $15 \mathrm{ppt}$ ) or too high (over $35 \mathrm{ppt}$ ). In addition, the high salinity indicates high levels of salt in the water so that it can affect the taste of Eucheuma after harvest.

\section{Seaweed Farmers Asset in Kepulauan Seribu District}

Seaweed farmer asset in Kepulauan Seribu District can identified through human capital, natural capital, social capital, physical capital, and financial capital. There are:

- Human capital - education, access to health facilities, skills.

- Natural capital - land, commodities, access to water.

- Social capital - relative that can financial support, members of certain associations, office.

- Physical capital - accessibility, building the house.

- Financial capital - yields, ownership of goods, income, savings.

Level of education of Kepulauan Seribu District, in general, can be seen by the number of schools, number of teachers, and the number of students. In 2013-2014, Kepulauan Seribu District has:

- Kindergarten (10 school and 44 teachers):

- Elementary School (14 schools and 207 teachers):

- Junior High School (7 schools and 97 teachers); and

- Senior High School (1school and 31 teachers).

Health facilities in Kepulauan Seribu District have 1 hospital, 15-bed, 2 sub-district health centers, and 4 village health centers (Centre of Data, Statistic, and Information, 2014).

Kepulauan Seribu natural capital asset could be identified through 110 islands with $8,71 \mathrm{~km} 2$ land area and $6.997 \mathrm{~km}^{2}$ sea area (Kepulauan Seribu District Statistic Bureau, 2015). The 110 islands consist of 11 settlement islands, 45 tourist islands, 26 conservation island, 17 island nature reserve, 3 heritage islands, 4 islands for special designation, and 4 sinking islands. If based on ownership, the island consists of 60 privately island/resort, 11 island residents, and 39 islands have government. In 2013, Kepulauan Seribu District could give Rp. 17.324.930.000, - from fisheries production and Rp.29.642.082.000, - from aquaculture.

Same like another small island, Kepulauan Seribu District has issues about the availability of clean water. Clean water crisis in Panggang Island, for example, is closely related to limited water resources, and the community's ability to pay. Until now, Panggang Island people use water from rain or buy from waterman. The decline in the water quality of groundwater indicates environmental degradation due to pollution from household wastewater and sea water. Households using bottled water and reverse osmosis (RO) in 2013 are $82.82 \%$.

Each settlement island in Kepulauan Seribu District has a pier for passenger ships and unloading or logistics. Regular transportation is available, both servicing between islands in Kepulauan Seribu District and between Kepulauan Seribu District and Jakarta. That pier serves ships to and from Jakarta Marina Ancol and Muara Angke port.

Communications network in Kepulauan Seribu District had begun in some islands. It is easier for people to communicate with each other and also with people outside the district. In 2014, approximately $89.77 \%$ of households in the Kepulauan Seribu already have a cell phone.

Social welfare in Kepulauan Seribu District can be seen from the quality of housing. In 2014, there were $42.32 \%$ of the houses have roofs; $99.90 \%$ already storey house; and $93.46 \%$ of the houses have been walled. Health quality factor residence can be seen from sanitation facilities. In 2013, households already have septic tanks (pit) of $71.27 \%$, the rest are still using the sea as a final disposal of feces.

\section{Seaweed Farmers Vulnerability in the Kepulauan Seribu District}

Kepulauan Seribu District faces several issues related to coastal community livelihood, such as (Head of Kepulauan Seribu District, 2015):

\section{- Clean water and electricity}

Issues about clean water and electricity are important in the development of small islands. Providing clean water and electricity in small islands require a large investment. Clean water in small islands can be provided through desalination, reverse osmosis, and water conservation program through infiltration wells. And the supply of electricity to the public is through submarine cables. Seaweed farmers need water in the washing process. And also electricity in seaweed processing into food products.

- Communications Network and Online Transaction

Currently, only a few of the island who has a provider tower. Especially in settlement and Resort Island. But it has not been able to serve the entire district. Communications network and online transactions are required for seaweed farmers to communicate with consumer and other partners. 
- Waste and Water Pollution

A large number of household in Kepulauan Seribu District produces domestic waste. And sometimes there is garbage that swept from Jakarta and makes water pollution in Kepulauan Seribu sea. Now, there is an incinerator and composting process to process waste. Waste that goes into the water can contaminate and interfere with seaweed growth. It's can lead to failed harvests or crops that are not growing optimal.

- Transportation

Kepulauan Seribu District still needs to develop safe and affordable regular transportation; find alternatives transportation alternatives; not yet completed the proper pier on every island; the lack of gas stations/fuel; and there is no special pier for passenger and pier for unloading or logistics. Transportation facilities in every island will help seaweed farmers in the provision seeds and farming equipment; selling the crop, and consulting seaweed cultivation issues with agencies or other experts.

- The EIA Study on Carrying Capacity of Small Island as permanent settlement

The EIA study including to local wisdom, breakwater use, and public transport. Especially on Panggang Island, Pramuka Island, and Untung Jawa Island. Study related to the carrying capacity of small islands required by seaweed farmers to identify the island (land and water) carrying capacity for seaweed cultivation area.

- Rules and Investment Facility

Fewer rules and the difficulties for investment can influence seaweed farmers in developing their cultivation activities.

- Human Development Index

This is related to preparing Kepulauan Seribu people became part of marine tourism communities (tourism awareness); improving the quality of education and health; and build public awareness of the potential of natural resources and local culture (local wisdom). With the high human development index in Kepulauan Seribu District are expected can support seaweed cultivation.

\section{E. Sustainability Seaweed Farmers Livelihoods in Kepulauan Seribu District}

Seaweed farmer's sustainable livelihood in the Kepulauan Seribu District analyzed by assets and vulnerable index. Such assets consist of Human capital, natural capital, Social capital, Physical capital, financial capital. And vulnerability seen by the water and electricity issues; network communications and online transactions; sewage water pollution; transportation;
EIA on small island carrying capacity; rules and ease of investment; and the human development index.

\section{CONCLUSIONS AND SUGGESTIONS}

A. Conclusions

Based on Kepulauan Seribu District asset, coastal community should improve individual and community asset to deal with shock. The coastal community vulnerable in natural capital, social capital, and financial capital.

Until now, seaweed cultivation has not been able to support the sustainability of livelihoods in Kepulauan Seribu coastal community.

\section{B. Suggestions}

In the future, we need to continue this research to find more detail about seaweed cultivation role for support sustainable livelihood in Small Island.

\section{REFERENCES}

[1] DKI Jakarta Province Disaster Management Bureau, 2011, "Rencana Penanggulangan Bencana Propinsi DKI Jakarta”, BPBD DKI Jakarta Province, Jakarta.

[2] Kepulauan Seribu District Statistic Bureau, 2015, "Statistik Daerah Kabupaten Kepulauan Seribu”, BPS Kepulauan Seribu District, Jakarta.

[3] DKI Jakarta Province Statistic Bureau, 2015, "Statistik Daerah Provinsi DKI Jakarta”. BPS DKI Jakarta Province, Jakarta.

[4] Head of Kepulauan Seribu District, 2015, "Materi Paparan Prioritas Pembangunan Wilayah Kabupaten Administrasi Kepulauan Seribu", Administration of Kepulauan Seribu District, Jakarta.

[5] Khotimah, H. 2015. "Teknik Budidaya Rumput Laut Eucheuma cottonii di Pulau Panggang, Balai Taman Nasional Kepulauan Seribu”, Field work report. Fisheries Department Faculty of Agriculture Gadjah Mada University, Yogyakarta.

[6] Kusnadi, 2009, "Keberdayaan Nelayan dan Dinamika Ekonomi Pesisir", Ar-Ruzz Media, Yogyakarta.

[7] Centre of Data, Statistic, and Information, 2013, "Profil Kelautan dan Perikanan Propinsi DKI Jakarta untuk mendukung Industrialisasi Kelautan Perikanan”, General Secretariat of Marine and Fisheries Ministry of Republic Indonesia, Jakarta.

[8] Centre of Data, Statistic, and Information, 2014," Kelautan dan Perikanan Dalam Angka 2014", Marine and Fisheries Ministry of Republic Indonesia, Jakarta.

[9] Saragih, S., J. Lassa., and A, Ramli, 2007, "Kerangka Penghidupan Berkelanjutan", Hivos-Circle Indonesia. 